\title{
Women and Make-Up: The Dilemma of Bourdieu's Subjectivism- Objectivism on Social Media
}

\author{
Suharnanik $^{1^{*}}$ \\ ${ }^{1}$ Department of Sosiology, Faculty of Social Science and Politic, Universitas Wijaya \\ Kusuma Surabaya, Surabaya, Indonesia \\ Jalan Dukuh Kupang XXV No. 54, Dukuh Pakis, Surabaya, Jawa Timur, Indonesia \\ Email: nanik_fisip@uwks.ac.id
}

\begin{abstract}
This research refers to the trend of women's makeup in the 2020 era, which is dominated by natural makeup. Influencers and makeup artists have a role in popularizing it. The author is interested in examining the makeup behavior in women with Bourdieu's theory. What behaviors make a woman look natural, prioritize skin health, minimal makeup. What culture is behind it. The findings of this study are all women like makeup, habitus leads to natural makeup. Habitus emphasized freedom in analyzing a practice as an agent and social structure. Women have a habitus in using makeup determined by a dual mechanism not just the dominance of social media factors, but also played by selffreedom as women as influencers in the social media itself. The arena is an environment where strength is at stake in the struggle over capital resources. Social media is an arena, a different social space, more enabling women to compete more dynamically in gaining position and legitimacy. Women use practices in makeup as a strategy in winning a competition. The makeup practice is an accumulation of women's capital and habitus, where every woman is different in her practice. The method used in this research includes in-depth interviews with women who use makeup, as well as literacy studies of the concepts of capital, habitus and the realm. The results showed that women undergoing their practice experienced "ambiguity" or dilemmas when using make-up strategies in their social arena.
\end{abstract}

Keywords: trend 2020, tastes, habitus, practice, natural.

\begin{abstract}
Abstrak
Penelitian bermula dari topik yang menjadi trend make-up perempuan dalam era 2020, ternyata yang prediksinya adalah natural make-up atau natural look. Prediksi ini muncul dari para influencer dan perias make-up artis yang sudah ternama, penulis tertarik mengkajinya dalam perspektif praktik Bourdieu. Perubahan yang begitu hedone dengan barang branded, muncul sebuah istilah kembali ke natural, tampil dengan make-up natural yang lebih alami mengutamakan kesehatan kulit. Temuan dari penelitian ini adalah bahwasanya hampir semua perempuan menyukai make-up, selera didominasi oleh make-up natural. Sementara bagaimana membongkar praktik menggunakan konsep habitus dan arena. Habitus menekankan kebebasan dalam menganalisa sebuah praktik sebagai agen dan struktur sosial. Perempuan memiliki habitus dalam bermake make-up ditentukan oleh mekanisme ganda bukan sekedar dominasi faktor sosial media, namun
\end{abstract}


juga diperankan oleh kebebasan diri sebagai perempuan sebagai influencer dalam sosial media itu sendiri. Arena merupakan lingkungan dimana kekuatan dipertaruhkan dalam memperebutkan sumberdaya modal. Sosial media merupakan arena, ruang social yang berbeda, lebih memungkinkan perempuan bersaing lebih dinamis dalam mendapatkan posisi dan legitimasi. Perempuan menggunakan praktik dalam ber-make-up sebagai strategi dalam memenangkan persaingan. Pratktik make-up merupakan akumulasi modal dan habitus perempuan, dimana setiap perempuan berbeda-beda dalam mempraktikannya. Metode yang digunakan dalam penelitian ini meliputi wawancara mendalam pada perempuan yang menggunakan make-up, serta studi literasi konsep capital, habitus dan ranah. Hasil penelitian menunjukkan bahwa perempuan dalam menjalani praktiknya mengalami "kemenduaan" atau dilemma ketika menggunakan strategi make-up dalam arena sosialnya.

Kata kunci: trend 2020, selera, habitus, praktik, alami

\section{INTRODUCTION}

The arena is Bourdieu's concept in explaining the social situation used by agents in fighting for position and legitimacy. The intended domain tends to be a social space filled with the accumulation of social capital as a basic dimension in social life. While social media such as Instagramm, Facebook, Twitter, web, and others can be categorized as virtual world social spaces that store various social dimensions that are different from real-world social spaces. This dimension in supporting social life in cyberspace is certainly different because events that occur can take place so quickly are more specific and the logic of practice that occurs also is different.

Social media is a domain that influences women in representing themselves. With convenience, it allows you to do whatever you want (Qi, Jiayin, Monod, Fang, and Dengab 2018). This influence can have positive and negative impacts. For women, online prostitution is a threat, in her research Listyani women can be trapped in online prostitution but families can anticipate it (Listyani 2017). While the value of online media can increase political participation for novice voters (Damanik 2018). Although we know that in politics it always raises social conflicts (Fauzi, Mudzakir, and Abdulrahim 2019). This media can also have implications for the dissemination of information in the academic environment (Meilinda 2018). Instagram, Facebook, and other social media platforms also function as a mirrored media for someone to be able to appear perfectionist (Hewit, Gordon, and Michael 2017). Without barriers, every social media can be a container and a mirror to behave in using makeup. Being a media to show the 
attitudes and behavior of women about many things, about how women take care of the family, run their profession, about building relationships and how women look (Vilhjálmsdóttir and Arnkelssonb 2013). Appearance in the form of fashion and makeup is also not out of his attention, product selection to how to determine trends of interest also uses social media as a reference. This article will thoroughly discuss the essential roles of media in determining trends and interests of women's fashion and makeup. Women are the target of cosmetics products, on the other hand, they can be the mediator for cosmetic producers in marketing their products. This article becomes interesting because it discusses the relations of women and cosmetics, analyses behavior from Bourdieu's perspective, and examines the occurred and undergoing events in our surroundings. Women's behavior is closely related to their daily life on how they represent themselves in public. This article uses primary data support and the research includes data collection using Google Form. Researchers collected the data on women's preferences of makeup choice and the budget spent on makeup tools.

As stated by Booth and Matic, about consumer tastes affected by influencers, through social media a person can become someone who is recognized even though he was not a famous person (Booth and Matic 2011). Likewise, in deciding to buy, compliance with a little doubtful material is determined by communication through Instagram (Martínez-Sanz and Fernández 2018). Referring to what was conveyed by Roger in, where every human being behaves well if there is a deviant behavior is a natural process of life development. Women trying to synergize with the makeup trend can be analyzed from this perspective is a natural phenomenon in social life. The tendency to follow the flow of the social field as an arena where social reality is formed is a social natural phenomenon in social life. People are influenced by their cultural capital, habitus and class - which, in turn, are affected by their life course experiences (Newman, Goulding, and Whitehead 2013).

Bourdieu's concept discusses social practice, is influenced by habitus and is then strengthened by capital and supported by the arena (Kitchin and Howe 2013). Women consciously and unconsciously have a united habitus in themselves to practice using makeup because it is strengthened by economic, cultural capital and then coupled with environmental conditions as a realm. That emotion management is part of a person's habitus (Addison 2017). Makeup trends may 
have been a long time practiced by women as their ancestors did. Like the culture of caring for the body with herbs, slimming herbs, traditional powder, skin and facial smoothing herbs, bathing flowers, and other rituals about female self-care. In the same context but different situations women as part of a culture that moves according to a standardized structure (Angus, Dale, Nielsen, Kile, Lapum, and Pritlove 2018). Is it possible for women to be the source of agents who become objects dynamically framing existing structures?

The novelty of this research that it will be the focus of discussion in this article, where women are not only produced by the media but are able to take part in producing media that inspire cases related to making up. This article also aims to anticipate various social problems caused by women's behavior caused by social media. Sometimes women need enlightenment, streamlining thinking patterns in preventing the detrimental effects of behavior such as eliminating selfconcepts that encourage consumer behavior, loss of self-confidence and even withdrawing from the social environment. That is what this article presents as a fairly accurate source of reference in theorizing and adapting to existing realities about women today.

\section{METHODS}

This research uses a descriptive approach to qualitative methods. The fact that women are more likely than men to participate in traditional high status leisure activities constitutes one of the most consistent findings in the empirical study of cultural choice (Lizardo 2006). The behavior of women using make-up that explains the interrelationship between existing data elements. Then conducted in-depth observations, conducting in-depth interviews and short surveys with an environmental scale. The observation was also carried out intensively to see and observe how women's behavior is affected by the media in applying their makeup. This research study uses a sociological approach that is more flexible in seeing phenomena that occur, where sometimes the actor moves and reacts by himself regardless of the standard structure, while on the other hand sometimes the actor is powerless in the existing structural frame. Therefore, the view of this theory is used in analyzing the phenomenon of makeup that is the practice of women, namely structuralism and existentialism Bourdieu. In its concept, this theory 
connects subjectivity and objectivity between agent and structure. His article (Crossley 2013), uses the concept of habitus in dealing with debates between habit and habitus. Meanwhile (Williams 2012), more emphasis on observation and analysis on different decision-making practices is carried out by lower socioeconomic groups with the top but with the same level of education. There is a link between habitus that is fully supported by capital, which has a valuable impact on education, although this is a challenge for the economically disadvantaged (Gaddis 2013).

This study was involving 53 female participants who apply makeup, ranging from 19 years old to 22 years old university students, plotting on campus in Malang and Surabaya. The participants filled in online questionnaires through the link provided expressing their opinion on applying makeup, interviewed and observed by the researchers.

In qualitative research based on contextual issues that are central to the strategy and there is a hidden agenda carried by researchers (Shaw and Gould 2001). This research focuses on social conditions that occur in women who prefer natural makeup trends. This phenomenon is very underlying to be part of qualitative research that tends to be contextual, reading and observing events with awareness motives. The awareness is aimed at anyone who sees the phenomenon in a balanced way, women are not victims of fashion trends but women as activists of trends. In addition, this article has the purpose behind a qualitative approach, namely the awareness behind the phenomenon of natural makeup. The data collected in this qualitative study is historical in nature, supported by Linkert scale data to see the pattern of support and enthusiasm to make-up users in terms of the nominal issued monthly. Observations made by researchers in enriching the supporting data to find out the reasons behind the use of makeup and explore some references related to the theories and themes taken. To enrich the data deepening, researchers approached and interviewed makeup users. Also observed media that affects makeup behavior.

This research is about observing behavior, as social research certainly prioritizes research designs that can be adapted to the social factual conditions to be studied (Walliman 2006). In the data analysis stage, the researcher uses the triangulation technique. What is meant by triangulation data is data information 
taken at different times, different places, different people (Miller and Brewer 2003).

The data was collected by using data triangulation. First, the researchers took data at different times. Second, the data obtained was confirmed to the same participant by repeating the questions at different places and different social settings. Third, the researchers confirmed the data obtained by comparing it with other participants using the same questions.

\section{RESULTS AND DISCUSSION}

The behavior of women who apply makeup is an important phenomenon that can be analyzed based on a sociological perspective. Therefore, some misunderstandings may occur and a balanced perception of women as a part of society is needed. Bourdieu states, the composition in building a practice is determined by the equation $($ Habitus X Capital $)+$ Arena $=$ Practice $($ Bourdieu 1977). Implementatively, the equality scheme can illustrate that women's practices in makeup are determined by their Habitus. Habitus and capital factors become the main components, habitus without being strengthened by capital will affect the results of the practice itself.

1. Women's practice in make-up

Figure 1

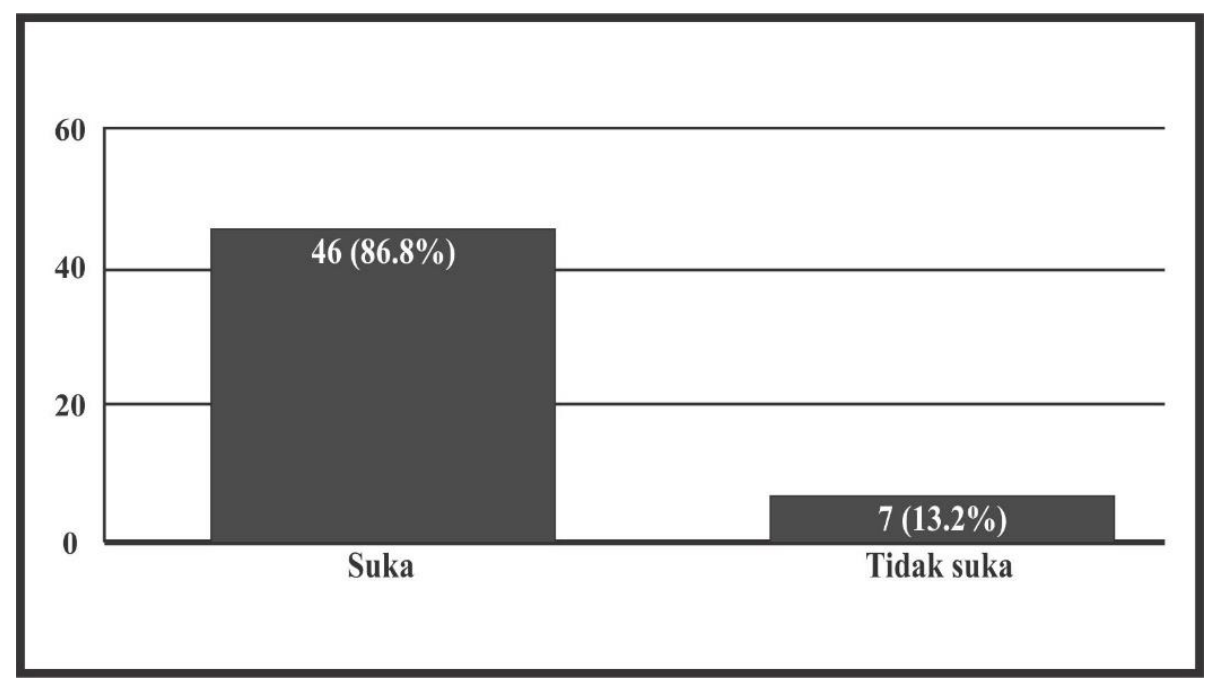

Data about the hobby of Make-up 
The data shows that $86.8 \%$ of women like applying makeup while $13.2 \%$ others do not. They prefer using makeup rather than not using makeup. It is practical because making up is a very complex for women related to their cultural background.

As a concept of practice, the discussion is deeper related to how women like the practice. In Bourdieu's concept, practice relates to capital, habitus and the realm. This means that the practice of women in using make-up must have a fairly well-established habitus, without being supported by material capital and cultural support that facilitates women in making use of these practices, these practices will not emerge. Meanwhile, economic and cultural capital is like a controlling component, which affects habitus becoming increasingly visible, the resulting behavior is also increasingly seen as practice. With its constituent elements in the form of capital, the behavior is more easily formed into signs and symbols that can be identified in a particular practice.

Capital as a support for the creation of habitus. Capital is like a multiplier for habitus, not being able to stand on its own into a pattern of behavior or skills that exist within the individual. Habitus without the support of capital then stands alone without any elements of its counterpart, so it tends to slow down, hidden in behavior as an identifiable practice. Women who have habitus in making up without being supported by social and economic capital can cause their habitus hampered or even not done anymore by women because they are not culturally supportive to make-up, while economic support is needed to buy goods like equipment and makeup materials. According to Bourdieu, the enabling conditions for using up are influenced by the realm, as a place where women are. The realm can be interpreted as a playground, its rules and arrangements are set within the community.

Based on the data, the majority of women stated that they like applying makeup. This preference is a practice due to most social media that review and visualize the cosmetics trends (Blasius and Friedrichsb 2008). Postings in social media indeed free women in determining their behavior whether or not using makeup. Some working women may believe that makeup strengthens them in taking roles structurally within the society and supports their self-confidence. But unfortunately, there are still many dilemmas about women's subjectivism towards social media. Women seem merely consumers of cosmetic products. But on the 
other hand, some women can produce makeup styles and even become product drafter and market the products on social media. The role of women as agents as well as structures is still open in this social media, even though it is still dominated as the user only. As a user means the dominance of the structure still strongly influences it, while the subjectivism which strengthens the agent as an influencer as a producer is still relatively minimal.

The construction of norms in building gender and media offers new, slightly complex and complex insights (Ross 2012). Similarly, the discussion in this article also gives a slightly confusing nuance, a categorical dilemma that is not easily taken for granted. When did women become part of the construction of social media and when did women become the result of the construction itself, But that is the reality experienced by women today, at least when dealing with the phenomenon of women in make-up. This phenomenon can be explained using Bourdieu's perspective on practice, the origins of structural construction and how actors are able to shape themselves in existentialism. In its explanation (Andreassen, Schou, Pallesen, and Griffiths 2017), it can provide enlightenment where women use social media, trapped in addictive conditions for the sake of self-esteem. Self-development that decides a woman's self falls in this practice situation is not fully explained in the article. so the explanation for women entering into these addictive conditions has historically not been explained, while the Bourdieu approach in this article can be explained how this can occur. As Bourdieu views this also found in (Suharnanik 2018), which discusses the practice of women in online trading. Discuss the history of the origin of women's life journey in the online realm. Habitus can be formed consciously and very naturally through the history of the past experienced by women.

\section{Habitus of women in make-up}

Habitus is the process of accumulating skills in influencing practical actions so that it becomes an individual's ability that seems natural. In Karnanta, habitus regulates how to behave, talk, and look at and understand the world (Karnanta 2013). The ability of women in applying makeup is supported by a culture that compares them as individual figures who must look beautiful using makeup. Makeup trends are more dominated by "natural look", this condition is influenced 
by the authority that shows the effectiveness of an appearance (Sinclair 2017). The appearance of women who seem natural is considered more effective than a glamorous appearance with thick makeup requires more cost and longer time. Effectiveness in appearance with the support of media authorities who campaign for care products is more favored than the striking change of makeup. Women's actions in regulating their performance as social actors do not just appear but are related to social investment formations. How women are able to absorb every cultural symbol in their society and then apply it as a way of appearance.

Figure 2

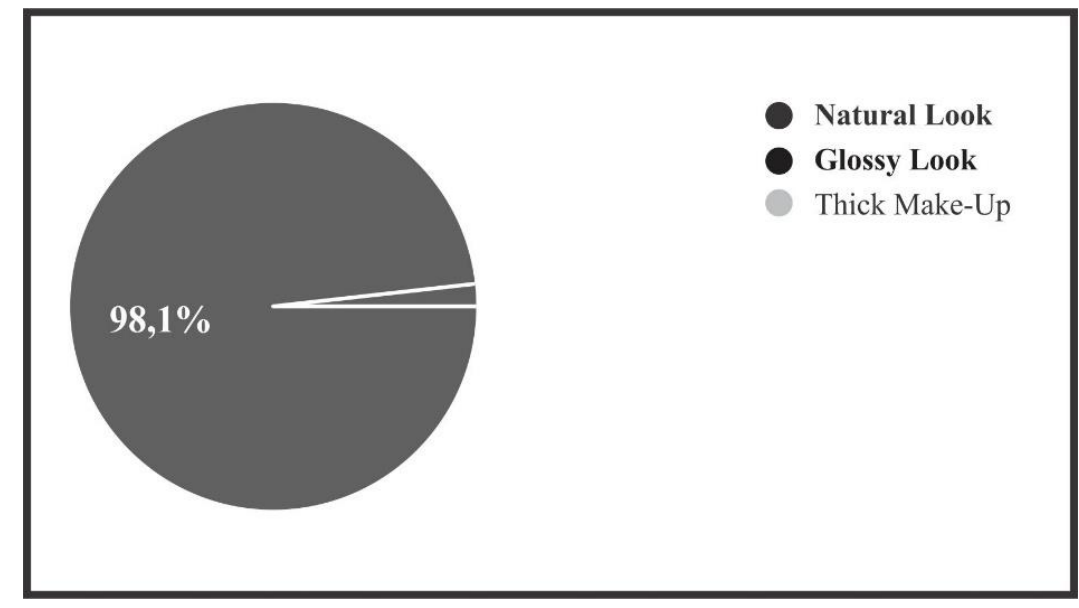

The preferred type of "make-up" data

From figure 2. The data shows that $98.1 \%$ of women prefer "Natural Look" in applying make-up. Things that can be explained with this taste concerning Bourdieu's concept related to taste or 'taste'. Taste is a grouping of lifestyles that occur in communities with the same habitus. This taste can be a systematic belief and practice into a social class opinion (Bourdieu 1993). To get recognition, many ways can be done, including improving skills, maintaining an attitude to be in tune with environmental conditions and always issuing ideas and ideas in any social environment. Bourdieu identified tastes based on the social class that became his lifestyle. Popular taste and legitimate taste, are the basis for the placement of tastes that occur in society. Is natural look a taste that is included in the category of legitimate taste, it could be the case with the following analysis. Natural makeup trends, makeup that is dominated by upper class, even contemporary artists, K-Pop also uses this trend. According to renowned MUA (make-up artist) Vinna Gracia, the use of makeup that appears natural is more focused on facial skin care. What is delivered by an expert in social media 
becomes a mediation of formality between producers to consumers, tastes that go through formal channels are more legitimized by middle and upper social groups who have higher education and high economic levels. Emphasis on skin care means that costs are increased on treatments not full covered makeup that tries to cover up the deficiencies and damage to facial skin. This means what, only socioeconomic groups and above can afford it, because the calculation is far greater than the cost of the family for treatment than the cost of makeup itself. This is the dilemma faced by women with social media that needs attention so that women think more critically. Media is supported by capitalist producers via numerous channels. So that the cultural values are supported and legitimated by the groups that are targeted for production. Some arenas forbid women from applying thick and conspicuous makeup, nevertheless, some others require the opposite. Events like wedding ceremonies, traditional ceremonies, parties and other formal events encourage women to use makeup. Using makeup is an arena symbol, which impacts social status symbols.

Demands both conscious and unconscious in an arena make women compete to follow these developments. Because, if women fail to identify the suitability of the realm with the practice of using up, it will be said to be a failure of fashion or misplaced with the popular term "saltum" wrong costume. For example, when attending a wedding party using thin make-up when it should be glamorous, while attending a recitation the use of thin make-up if using glamor is considered publicly inappropriate, less ethical and disrespectful. Female beauty standards do not vary across countries, but along lines of (emerging) cultural capital and gender (Kuipers 2015).

Bourdieu, understanding practice is not just about how behavior and actions are carried out by someone. Behavior being discussed so far based on several components of participation, which are habitus, capital and realm. Forming elements of practice turned out to be very complex. Even when a temporary behavior appears, it can be called as a practice, because practice shows a pattern that underlies that particular behavior. Women who apply makeup only at their wedding is also called as practice. Women historically apply makeup on their wedding as part of the tradition, despite of their preference. Social media nowadays preserves the fact. 
Women become actors in determining fashion as well as being a victim of the fashion make-up trend itself. By following the content of social media, women can do anything even if sometimes not suitable for their conditions, as long as they are confident in doing so. Consumtive culture creates women as objects of social media structures, which are part of cosmetics producers. Women who are trapped in this trend, experience changes in consumption patterns that prioritize the appearance of the needs of education, self-development and other basic needs. There is not even a clear definition of which needs are 'need' and which are just 'want', because everything has been obscured. Bourdieu constructs the origin of the structure of how these patterns of behavior are formed, the media being one of the structures that most strongly influences it. The media always creates consumers to have buying behavior with various slogans, marketing words in the form of discounts, new models, promo vouchers and so forth. Though it all is just a trick as a surefire way in building consumer behavior to buy. Media construction through legitimacy can be done by getting support from the woman herself who is the target of cosmetic beauty products, support from the woman herself reinforces the recognition of her fellow women users. That is the origin of how a structure can influence a woman's practice in using cosmetics.

How to build awareness in dismantling the role of the construction of social media on the phenomenon of make-up practices in women. There are a number of things that can be done including: first, it requires deep thinking, that is deep thinking. Because social media is now getting smarter at trapping consumers to buy a product, it involves writers who are able to review their products in great detail. It is undeniable that even women are involved in discussing new products that have just been launched by creating a public interest to legitimize (recognize) that this product is very different and must buy it. Think deeply, what you want to be produced from makeup. A makeup that you want does not always require a new product, it does not always have to be tempted by discounts because discounts are a Batman trap for consumers to spend their money. Second, financial intelligence is needed to manage a practice in cosmetics not only as an object but also as a subject that builds the behavior itself. Awareness in controlling oneself so that financial bets can be spent according to needs not wants. Buy cosmetics if your cosmetics are used up, don't even think about buying for stock at home, remember that every cosmetic has expired. And the third is to 
create a practice that involves emotional intelligence and social intelligence. Do the practice not because it is merely imitating others, pleasing others. Women wear electricity, makeup, eyeliner, eyelashes to look perfect. Every time there is social media that promotes cosmetics, he buys it. Especially if you make-up with an excuse for something or someone, you should do it to please yourself. Do it if it makes yourself comfortable as a woman, without pressure, trying to increase self-confidence and try to be more productive in the life she lives.

\section{CONCLUSION}

The behavior of women in using cosmetics in Indonesia is likely to increase in 2020. This study shows data of women who practice using makeup as the realm of cultural production. The media has a role in producing culturally agreed upon. This concept is able to explain and analyze a combination of women's capital and strategies for using makeup. In a certain period of time using thick up is a common thing, but because of changing culture and media propaganda causes the trend to decline. When the culture driven by the media has campaigned for natural makeup trends, experiments are conducted with several arguments for health advantages with women's standards of politeness that are more elegant and dignified that deserve to be respected not just being beautiful but rather emphasizes self-competence making natural choices more desirable. Beauty products benefit in the treatment session rather than appearance, while products that emphasize thicker cosmetics have sharply decreased demand.

The improvement in the practice of using women is also supported by the ability of women involved as workers to improve their ability to determine attitudes and tastes according to their decisions. The decision in making up becomes a more active self-image of women in the world of work. Likewise, women who are active in the public sphere emphasize performing in cosmetics, despite choosing a natural look. The decision to buy or not will be dominated to buy beauty products, with reasons for the sake of the husband or for increasing self-potential and self-confidence. Furthermore, Bourdieu said that in presenting a particular practice, if there is a habitus that is strengthened with economic, social and cultural capital it will be a component that involves the double habitus itself. Then the combination of habitus with existing capital supported by the right 
arena, the practice will be more apparent. There fore the factor of women practicing in using up is determined by the behavior of using up that accumulates in a habitus then is strengthened with adequate capital economically and culturally. Accumulation of women's habitus in using up coupled with the right arena, matters of taste are determined by papular taste or legitimate taste. So far, the name of the makeup must be visible, meaning that the makeup is thick, glossy or bling-bling. However, the trend has changed, so determining which legitimate tastes with popular tastes is somewhat ambiguous, requires deeper study. Once blood cosmetics were popular tastes, it was supported by many people who liked this taste. However, some media by voicing health experts too covered make results in decreased skin health so that tastes change with natural makeup. This is why natural taste is included in the category of taste legitimacy because what party has the power of knowledge, in this case, is skin medicine that encourages such tastes to shift to formalized tastes, taste legitimacy.

Another factor that drives women to make-up is the contribution of women as users as well as influencers in the endorse frame of their marketing program for certain beauty products. The contribution of women who use cosmetics as well as business people also encourages growth in the use of makeup for women for the coming year. With this practical theory approach, making women have a certain practice that is not necessarily a mere consumer, but there is another awareness that must be revealed. As a dynamic human, of course, forming the habitus in women is not merely an object of the makeup trend, but is able to be the subject of the trend determining itself. The position of women in the narrative of Bourdieu's concept can be called the dilemma of subjectivism-objectivism towards social media that influences women in using up. E-commerce technology support, the cosmetic market potential for Indonesian women is increasingly promising.

\section{REFERENCES}

Addison, Michelle. 2017. "Overcoming Arlie Hochschild's Concepts of the 'Real' and 'False' Self by Drawing on Pierre Bourdieu's Concept of Habitus." Journal of Emotion, Space and Society 23:9-15.

Andreassen, Cecilie Schou, Ståle Pallesen, and Mark D. Griffiths. 2017. "The Relationship between Addictive Use of Social Media, Narcissism, and SelfEsteem: Findings from a Large National Survey." Journal of Addictive 


\section{Behaviors.}

Angus, Jan E., Craig M. Dale, Lisa Seto Nielsen, Marnie Kramer-Kile, Jennifer Lapum, and Cheryl Pritlove. 2018. "Gender Matters in Cardiac Rehabilitation and Diabetes: Using Bourdieu's Concepts." Journal of Social Science and Medicine 200:44-51.

Blasius, Jörg and Jürgen Friedrichsb. 2008. "Lifestyles in Distressed Neighborhoods: A Test of Bourdieu's 'Taste of Necessity' Hypothesis." Poetics Journal 36(1):24-44.

Booth, Norman and Julie Ann Matic. 2011. "Mapping and Leveraging Influencers in Social Media to Shape Corporate Brand Perceptions."” Corporate Communications: An International Journal Vol. 16 No:184-91.

Bourdieu, Pierre. 1993. "The Field of Cultural Production." Essays on Art and Leissure, New York: Columbia University Press.

Crossley, Nick. 2013. "Habit and Habitus." Journal Body and Society. 19(2-3), 136-161. https://doi.org/10.1177/1357034X12472543

Damanik, Erond L. 2018. "Whatsapp Dan Pemilih Pemula Di Kota Medan: Partisipasi Politik Era Demokrasi Digital Pada Pemilihan Gubernur Provinsi Sumatera Utara 2018." The Journal of Society and Media 2(2):81-108.

Fauzi, Agus Machfud, Moh Mudzakir, and Mohamed Omar Abdulrahim. 2019. "Social Conflict In Contestation Of Indonesia Election." The Journal of Society and Media 3(2):159.

Gaddis, S. Michael. 2013. "The Influence of Habitus in the Relationship between Cultural Capital and Academic Achievement." Journal Social Science Research.

Hewit, Paul L., Flett Gordon L, and Samuel F. Mikail. 2017. Perfectionism: A Relational Approach to Conceptualization, Assessment, and Treatment. New York: The Guilford Press.

Karnanta, Kukuh Yudha. 2013. "Paradigma Teori Arena Produksi Kultural Sastra: Kajian Terhadap Pemikiran Pierre Bourdieu." Jurnal Poetika Vol 1(1).

Kitchin, P. J. and P. David Howe. 2013. "How Can the Social Theory of Pierre Bourdieu Assist Sport Management Research?” Journal Sport Management Review 16(2):123-34.

Kuipers, Giselinde. 2015. "Beauty and Distinction? The Evaluation of Appearance and Cultural Capital in Five European Countries." Poetics Journal 53:38-51.

Lizardo, Omar. 2006. "The Puzzle of Women's 'Highbrow' Culture 
Consumption: Integrating Gender and Work into Bourdieu's Class Theory of Taste." Poetics Journal 34(1):1-23.

Listyani, Refti Handini. 2017. "Pencegahan Praktik Prostitusi Online Melalui Lembaga Sekolah Dan Keluarga.” The Journal of Society and Media 1(2):67.

Martínez-Sanz, Raquel and Cristina Gónzález Fernández. 2018. "Brand Communication on Instagram, a Gender Issue? The Role of the Fashion Influencer." Masculinities and Social Change Vol7, No 3.

Meilinda, Nurly. 2018. "Social Media on Campus: Studi Peran Media Sosial Sebagai Media Penyebaran Informasi Akademik Pada Mahasiswa Di Program Studi Ilmu Komunikasi FISIP UNSRI." The Journal of Society and Media 2(1):53-64.

Miller, Robert L. and John D. Brewer. 2003. The A-Z of Social Research. London: SAGE Publications Ltd.

Newman, Andrew, Anna Goulding, and Christopher Whitehead. 2013. "How Cultural Capital, Habitus and Class Influence the Responses of Older Adults to the Field of Contemporary Visual Art." Poetics Journal 41(5):456-80.

Qi, Jiayin, Emmanuel Monod, Binxing Fang, and Shichang Dengab. 2018. "Theories of Social Media: Philosophical Foundations." Journal of Engineering 4(1):94-102.

Ross, Karen. 2012. The Handbook of Gender, Sex, and Media. Wiley-Blackwell. https://doi.org/10.1002/9781118114254

Shaw, Ian and Nick Gould. 2001. Qualitative Research In Social Work. London: SAGE Publications London.

Sinclair, Aimee. 2017. “'It's a Real Negotiation within Yourself': Women's Stories of Challenging Heteronormativity within the Habitus." Journal of Women's Studies International Forum 64:1-9.

Suharnanik. 2018. "Perempuan Dan Teknologi Informasi Dalam Perspektif Cyberfeminist.” Journal of Urban Sociology 1(2):4.

Vilhjálmsdóttir, Guðbjörg and Guðmundur B. Arnkelssonb. 2013. "Social Aspects of Career Choice from the Perspective of Habitus Theory." Journal of Vocational Behavior 83(3):581-90.

Walliman, Nicholas. 2006. Social Research Methods. London, New Delhi: SAGE Publications India Pvt Ltd.

Williams, Karen Abigail. 2012. "Low-Income Students and Expensive, Highly Ranked Private Colleges: An Investigation of the Role of Habitus on College Choice and Debt Tolerance." 